\title{
Hyperthermic ablation by UltraSound Guided High Intensity Focused Ultrasound (USgHIFU) plus Systemic Chemotherapy (SC) for locally advanced pancreatic cancer: the secret of longer survival
}

\author{
Joan Vidal-Jove*, Eloi Perich, Marta Garcia-Bernal, Manuel Alvarez del Castillo \\ From 2nd European Symposium on Focused Ultrasound Therapy \\ Rome, Italy. 10-11 October 2013
}

We describe results in unresectable pancreatic tumors treated with USgHIFU hyperthermia ablation plus adjuvant chemotherapy.

\section{Materials and methods}

Forty three cases of non resectable pancreatic tumors were treated from March 2010 to March 2013, and all of them underwent systemic chemotherapy. Clinical responses (thermical ablation achieved) were measured by image techniques. They were 29 Stage III cases and 14. Stage IV cases. Complications were also analyzed.

\section{Results}

Clinical responses (ablation obtained) were $82 \%$ in all cases, sustained at 8 weeks of the procedure. We obtained 10 complete responses $(25 \%)$ at the end of the combined treatment, 9 from stage III patients and 2 from stage IV. Major complications included severe pancreatitis with GI bleeding (1), skin burning grade III that required plastic surgery (2). No deaths were registered. Median Survival was 13 month (6 mo - 2.7 year).

\section{Conclusion}

HIFU plus SC is a potentially effective and safe modality for the treatment of unresectable pancreatic cancer.

Published: 10 December 2014

Hospital University Mutua Terrassa, Barcelona, Spain
doi:10.1186/2050-5736-2-S1-A6

Cite this article as: Vidal-Jove et al:: Hyperthermic ablation by UltraSound Guided High Intensity Focused Ultrasound (USgHIFU) plus Systemic Chemotherapy (SC) for locally advanced pancreatic cancer: the secret of longer survival. Journal of Therapeutic Ultrasound 20142 (Suppl 1):A6.
Submit your next manuscript to BioMed Central and take full advantage of:

- Convenient online submission

- Thorough peer review

- No space constraints or color figure charges

- Immediate publication on acceptance

- Inclusion in PubMed, CAS, Scopus and Google Scholar

- Research which is freely available for redistribution

Submit your manuscript at www.biomedcentral.com/submit
( Biomed Central 